\title{
Visual merchandising an impulsive reinforcer of purchases leading to social imbalance: a case study on middle class families in Hyderabad.
}

\author{
RamaRao Mopidevi, Sree Rama Lolla \\ 1(Master of business administration/Nagarjuna University, India) \\ 2(Master of business administration/ $j$ N T University, India)
}

\begin{abstract}
Retailing in India is one of the pillars of its economy and accounts for 14 to 15 percent of its GDP. The Indian retail market is estimated to be US\$ 450 billion and one of the top five retail markets in the world by economic value. India is one of the fastest growing retail markets in the world, with 1.2 billion people. In order to attract the mass market retailers are adopting various promotional strategies, among them pioneer is visual merchandising. Visual merchandising is the activity and profession of developing the floor plans and threedimensional displays in order to maximize sales, Both goods and services can be displayed to highlight their features and benefits. The purpose of such visual merchandising is to attract, engage and motivate the customer towards making a purchase.

The Indian middle class is estimated to be 250 million people, by McKinsey \& Company, It will reach 600 million by 2030. According to Deutsche Research the estimates are nearly 300 million people for all Middle Class. India aims to eradicate poverty by 2020. The main purpose of this study is to explain the various consequences occurred in the middleclass families due to impulse purchases made by the family members, who were attracted by the window displays of retailing in the name of visual merchandising
\end{abstract}

Keywords - Autonomy, Mannequins, Props, Stimuli, Visual merchandising.

\section{Introduction}

Almost everything we use in our daily lives including the food we eat, the clothes we wear, and the Things we need for our homes or for ourselves are bought from Retail Stores. Goods are manufactured all over the world but are ultimately sold to us through these Retail Stores. Retailing is the business of buying goods in large quantities from a manufacturer or a wholesaler and, Then selling these products and services to Consumers for fulfilling their personal or family needs.

A Retailer is, in fact a person who specializes in selling certain types of goods and / or services to Consumer's for their personal use. Global Retailers in the World are Wal Mart(USA),Kroger(USA)Sears(USA)Metro - AG(GERMANY), Carrefour(France).Various Retail Formats are Convenience Stores, Specialty Stores, Super Markets Discount Stores, Combination Stores, Department Stores, Hyper Market, Ware House Stores, and Shopping Malls.

\section{Retailing In India}

India today is Dynamic Combination of Demanding Consumers, Rising Levels of Consumption and a growing Population Base. India is currently the Twelfth largest consumer market in the world. It is believed that 21 million people are employed in the Retail Sector in India, which is 7\% of the Total National Workforce. It is estimated that an 8 Million Jobs will be generated through Direct \& Indirect Employment related to the retail sector. In the year of 2012 the Indian retail market was estimated at $\$ 450$ billion US Dollars of which the organized market is estimated to stand at $\$ 250$ billion. The Large number of Research Houses, Consultants and Industry federations has speculated on the size that Indian Retail is likely to touch in the years to come. A common refrain has been that organized retail in India is expected to grow at 25-30 percent per annum in the next 5-6 years, while total retail as a sector would grow at the rate of 5\% per annum. 


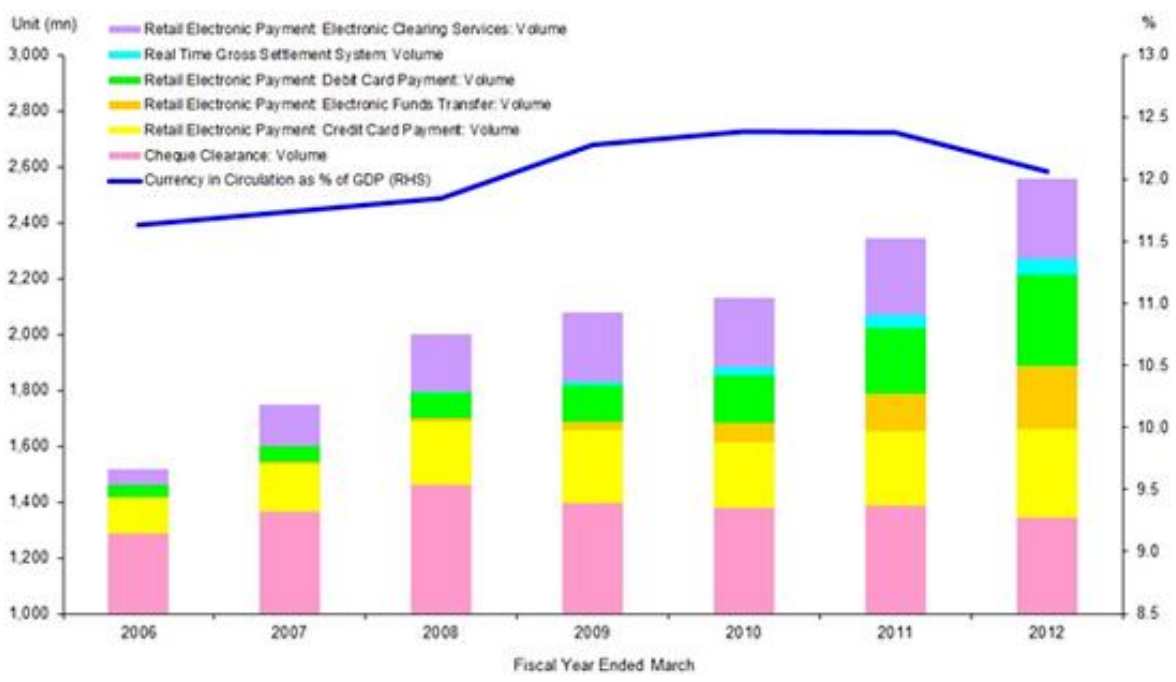

II.I RETAIL STRATEGIES; Retail Strategy is defined as ' a clear and definite plan that the retailer outlines to tap the market and Build a long-term relationship with the consumer. The prominent strategies of retailing are listed Like Store Location, Merchandising, Pricing, and Visual Merchandising.

II.II VISUAL MERCHANDISING; The display of products which makes them appealing, attractive, accessible, engaging, and enticing to shoppers in a retail store Visual merchandising utilizes displays, color, lighting, smells, sounds, digital technology and interactive elements to catch customers' attention and persuade them to make purchases. Visual merchandising helps convey the image of the brand and reflects the personality of the target markets that the retail store wants to attract.

Also Known As: product merchandising, retail display, merchandising design

II.III VARIOUS TOOLS IN VISUAL MERCHANDISING; All the elements of the store can play a role when it comes to creating a visual impact on the consumer. Apart from using the products to make a visual impact on the consumer some of the commonly used ones are: Colors \& Textures, Fixtures and merchandisers presentation, Signage's, windows, props, lighting and mannequins.

\section{Color and Lighting:}

Color contributes significantly to people's impression of a display as well as stores overall appearance. Color in a display can catch eye and make people pause and look. The color combination of ceiling, walls, floor covering and the overall décor can affect the atmosphere of a store. Changing the color scheme can change people's attitudes and perceptions of a store and can increase or decrease the business. Color can change the shape and interest to dull room, and can direct attention toward a specific object or away from problem areas. Warm colors (red, yellow, orange etc.) are stimulating and cheery. They make room feel warm and intimate. They make room look smaller and object inside larger.

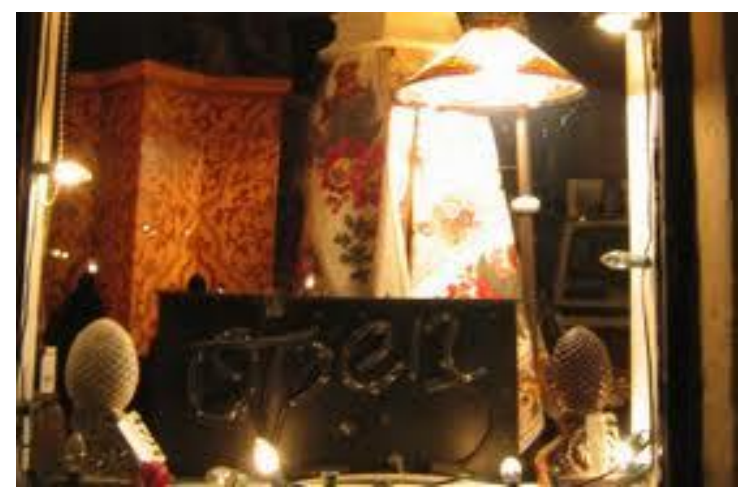




\begin{tabular}{|l|l|}
\hline Color & Emotional Response \\
\hline Blue & $\begin{array}{l}\text { A cool color (makes room seem cooler). } \\
\text { Calms and relaxes excited people. Makes } \\
\text { time seem to pass quickly. Tends to } \\
\text { stimulate thought processes and encourage } \\
\text { conversation. }\end{array}$ \\
\hline Green & $\begin{array}{l}\text { Easy on the eyes. A cool color. Restful and } \\
\text { tranquil. Stimulates conversations. Makes } \\
\text { time seem to pass quickly. }\end{array}$ \\
\hline Red & $\begin{array}{l}\text { Excites and stimulates. Induces aggression. } \\
\text { Makes time seem to pass more slowly. }\end{array}$ \\
\hline Yellow & $\begin{array}{l}\text { A cheerful color. Creates a feeling of } \\
\text { warmth and happiness. Draws attention. } \\
\text { Boosts morale. }\end{array}$ \\
\hline Orange & Friendly, warm and vibrant. Exhilarating. \\
\hline $\begin{array}{l}\text { Violet and } \\
\text { Purple }\end{array}$ & $\begin{array}{l}\text { A cool color. Tends to lend elegance and } \\
\text { sophistication. Royal. }\end{array}$ \\
\hline Brown & Relaxing and warm. \\
\hline Gray & Depressing. Cool. \\
\hline
\end{tabular}

Textures ; Texture deals with the look and feel of materials. Visual texture is the result of light refracted from any surface. Tactile texture can be rough smooth, thick, thin, sandy, soft, hard warty, coarse, fine regular or irregular. The combination of visual and tactile texture provides a definite interpretation encountered.

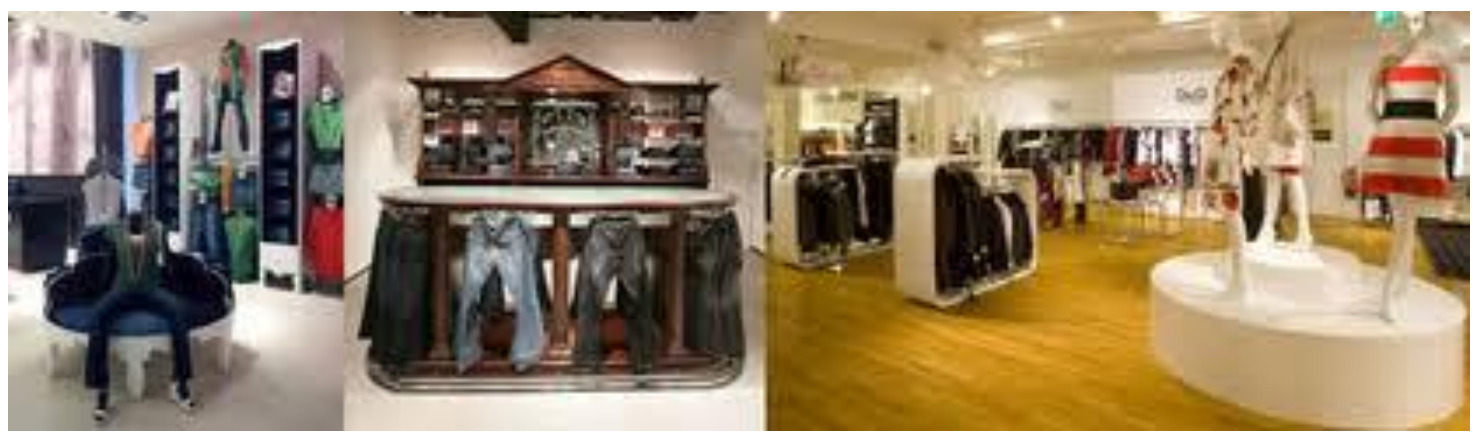

\section{Merchandise and Fixture Display \\ Recommendations:}

Goods can be effectively displayed on a variety of fixtures such as gondolas, tables, cubes, and mannequins, waterfalls and other racks, display cases. A fixture should not only complement the merchandise but also create an atmosphere in the store. It should act as silent sales person. One of the most common fixtures in store are gondolas; movable shelving approachable from all sides used in self-service retail stores to display merchandise. They can be lined up in stores as grocery or hardware stores.

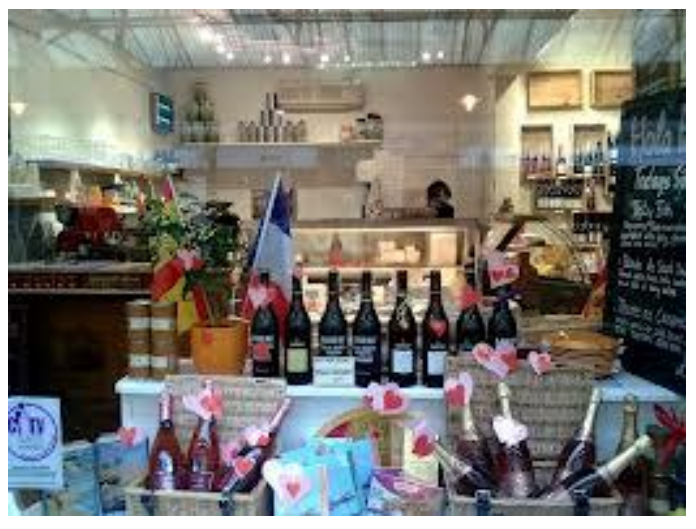

\section{Exterior Signs:}

A sign is a silent salesperson, and part of a shopper first impression of a store. In less than $10 \mathrm{sec}$ the sign must attract attention, tell what the business is and what it intends to sell. Simple, brief, well designed, well lettered and easy to read signs will convey a feeling of welcome. Design graphics appropriate for the nature of the business, and create a message that is clear and simple. Focus on one or two key words to describe the business. A clean, clear message will have more impact. A store sign is its "signature". It is personal, original and continuously recognizable to the public. It should create an image that is consistently

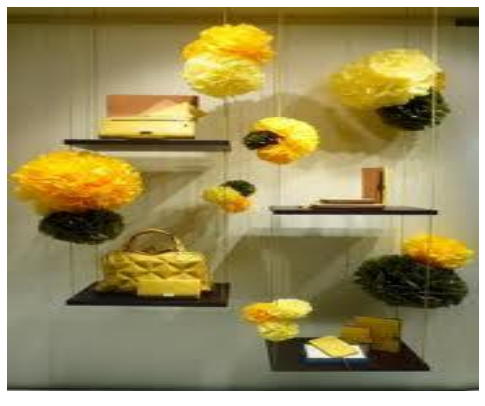


carried throughout the existence of store.

\section{Window Display:}

Special emphasis should be placed on a stores window displays because they are the information link to the potential customer. Window displays can be as important, if not more important than advertising. As many as four sales could be the result of a good window display .window display should attract attention, create interest and invite people into the store to purchase goods. There is less than 11 seconds to accomplish this, as that is an average amount of the time an individual will spend looking at a window display. Be careful not to crowd too much merchandise into a window, as customers will find it difficult to understand the message and what items are being promoted .It is important to change the displays frequently in small towns where customers pass by several times a week. New displays indicate new upto-date merchandise is available.

\section{Props and Fixtures:}

A prop is something used with a product in a display that clarifies the function of the merchandise being sold or the story being told. Props are integral part of a display. They are used in virtual merchandising to tell a story about the product A display prop may be something that is not for sale, such as floor coverings, wall treatments, backgrounds, mannequins, shelves and steps. When using saleable merchandise as prop, be sure it is appropriate for the theme of the display and is sufficient quantity to meet an increase in demand arising from the display.

Props can be items carried in from the woods or prairie, or rustic antiques found in someone's attic. Examples include a branch from lilac bush for spring summer collection, shocks of wheat, dried leaves, large boulders used to give an idea of strength and power of a tractor, and gray rocks to provide contrast to jewelry. These objects props are generally not beautiful by themselves, but highlight the merchandise for sale. The merchandise in a display must be the dominant element. The prop is there to complement or highlight the salable merchandise and add visual excitement to the surrounding area. A prop is not there to distract customer from their original purpose of shopping for and purchasing goods.

\section{Lighting:}

Lighting is essential in calling attention to merchandise in a display. A shopper's eye is drawn automatically to the brightest item or area. Lighting treatment may be used to draw attention to the part of display area or to coordinate the parts of total display area. Lighting can also be used to direct the path of the customers and to make them see various displays along the way. There are three types of lighting used:

1. Primary lighting

2. Store illumination

3. Atmosphere lighting
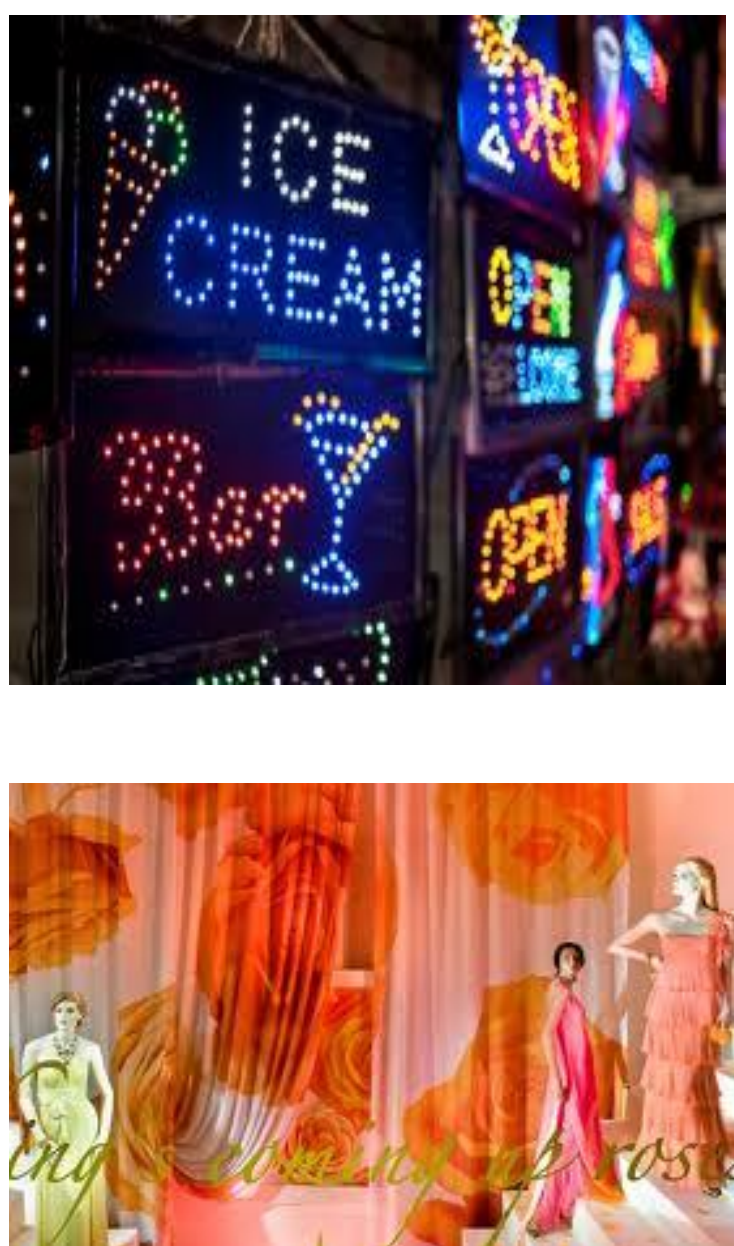


\title{
Primary Lighting:
}

Primary lighting is the overall level of illumination of the store using fluorescent or incandescent light sources. Outside, it includes 150 watt bulbs used as basic window lighting, marquee lights illuminating the sidewalks and lighting for generals lobby area. Inside the store primary lighting is that which fills the selling floor from overhead lighting fixtures and provides the bare essentials of store illumination.

\section{Accent or Secondary Lighting:}

This type of lighting provides illumination for designated display areas. Flat, shadow less, overall lighting can create a tiresome selling floor. Accent lighting provides change from light to dark highlight to shadows to prevent the boredom. This can be accomplished from down lighting from ceiling, showcase lighting and valence lighting (drapery or canopy). Incandescent bulbs are most often used for secondary lighting. They range I size from tiny Christmas trees light to small candle like or complexion bulbs, to full size globe or reflector

type

bulbs.

\section{Atmosphere Lighting:}

Atmosphere lighting is used to play light against shadow to create a distinctive effect on specific displays. Generally this category includes the use of color filters, pinpoint spotlights and black lighting to create dramatic effects. Fluorescent lights are used for primary lighting, as they cannot be focused directly on an object. Incandescent lamps have sharply defined beams that are easily directed to highlight the merchandise on display. Spotlights are great for merchandise displays. The angle at which spotlight is directed is very important. Any angle sharper than 45 degree is likely to momentarily blind a shopper. Color filters that change the color of the spotlight are available for spotlights. Gels are colored acetate that can be placed over light bulbs. They are similar to filters but are less expensive. They are available in roll form and can be easily cut to fit the light. High intensity discharge lamps are the most efficient bulbs available because they provide more light per watt. They help in reducing the cost and is also flattering to customer.

\begin{abstract}
Mannequins
the word mannequin comes from the Dutch word Mannequin, literally meaning little man. Mannequin is the French form. Mannequins are typically used in a retail store environment to display the merchandise. There are many types of mannequins available; the most common type is the life size mannequin. These mannequins are the same size as a real person and have arms, legs, hands, feet and a head. Mannequins can look like males, females or children. Other mannequins consist of only a torso on a stand.
\end{abstract}

\section{The Planogram}

A planogram is a tool used by the retailer that helps determine the location of merchandise within a department. It is a diagram that visually communicates how merchandise and props physically fit onto a store fixture or window to allow for proper visibility and price point options. A planogram is created after taking into account factors like products sales, the movement of the products within the product category and the space required for various products. They usually list the exact number of square feet used for various products and the exact number of product to be displayed in a particular area.

For retailer who has a number of stores spread over various
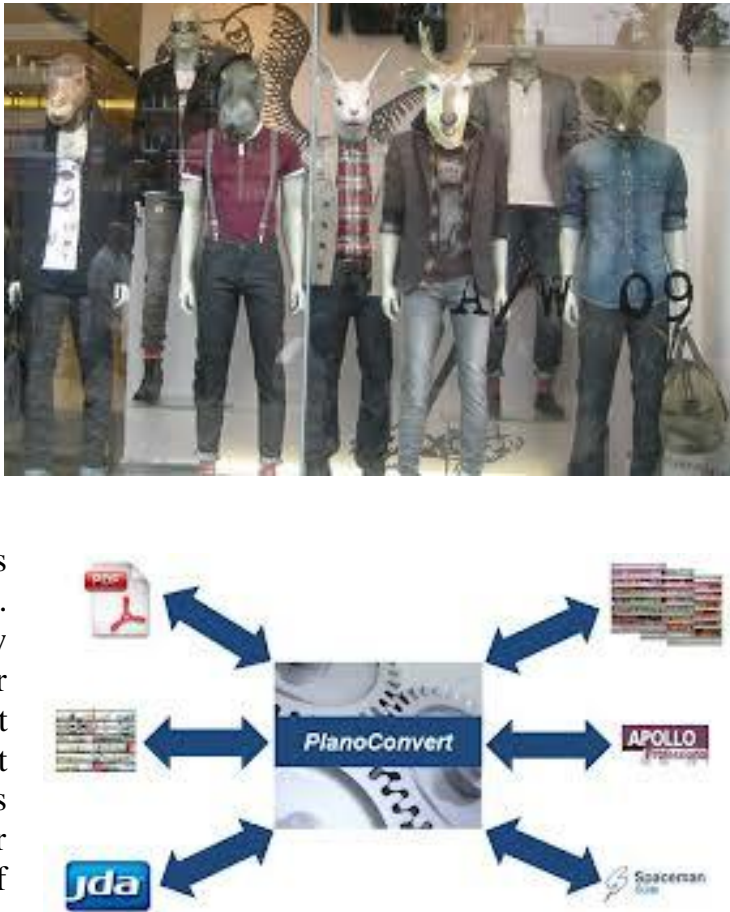

Flexible input - oustomized output

locations, a planogram is a good way to communicating how displays are to be done. This allows consistency in presentation across locations. When products are presented in the same manner across locations, the customers feels familiar and comfortable at each location. This helps to build brand loyalty and customer trust. 
II.IV.IDEALOGY OF VISUAL MERCHANDISING; Visual merchandising today forms a critical element of retailing. Besides the facade and windows, which are clearly done up with an objective to attract passer-bys and induce walk-ins, there is also in-store decor that is designed to enhance the customer's comfort and convenience while shopping and overall, offer a superior shopping experience .Once customers walk in, it is but imperative to ensure that they enjoy their first encounter with the store. After all, repeat visits will only happen if a customer's first visit is a memorable one. The logical arrangement of counters, with clear passageways allows for easy access to merchandise. Rather than getting lost in the maze that most large stores are, the customer feels more in control. Space is allocated to various product categories taking into account the number of SKUs stocked and shelves/counter space requirements are worked out accordingly .Clear passages are provided for products, which require touch and feel. All impulse purchase driven products are also clearly displayed so that the customers can reach them without any hindrance. Also, it has been observed that when a person enters a room, the human eye moves in a $\mathrm{Z}$ pattern, i.e. from rear left of the room to right rear, followed by front left of the room to front right. Care should be taken to do up the rear left end of the room in an appealing manner so as to guide the direction of vision and keep a shopper visually interested. A great deal of research has been undertaken on the impact of lighting on a customer's purchase behavior. Results clearly indicate that in general, stores that are brightly lit, with the lights cleverly blending with the interiors lead to higher customer comfort, and as such, more sales. Different types of lighting and interiors are used on different floors, the change reflecting the various products that are on display on a particular floor, the proposed target audience and the time of the year. The ladies floor, for instance, is most often subtly lit with soft lights or then again, in summers, cool bluish lights are used to impact an impression of coolness and comfort. The careful use of spotlights helps add to the appeal of products such as crystal and jewellery. Signage related to various product sections are put up clearly to demarcate areas, allowing customers a clear understanding of what is stocked. Where with various brands having their own pull, brand signage are also put up within the product sections so that customers can find their favorite brands easily. Additionally, within the product sections, signage helps to publicize the various promotional schemes that might be running in the store. Stores also make use of signage to indicate the facilities/services available at the store, such as washrooms, cafe etc. Most stores have an in-house team of visual merchandisers who coordinate with the marketing team as well as the in-house merchandisers and suppliers. Each time any major changes in decor are contemplated, they present the visual display concepts to the group for analysis and selection. Subsequently, the same is executed. The visual merchandising team also makes projections vis-a-vis returns per sq. ft. for each section and each brand stocked. On promotions related visual merchandising, the inputs of the advertising agency are also sought so that the in-shop communication is in line with the tactical promotions advertising. With cost of visual merchandising generally amounting to $1 \%$ of sales, this is one communication tool that clearly has an edge over others in terms of drawing in shoppers, increasing flow of traffic and increasing sales.

\section{II.V OBJETIVES OF VISUAL MERCHANDISING:}

\section{- Store Image}

Visual merchandising elements -- decor, logo and interior design -- set a retail store's image, or brand identity, and distinguish the business from its competition. Lighting, fixtures, music, color and product placement work together to establish an atmosphere that complements and supports that image. Even the look of the shopping bag, notes renowned visual merchandising Martin Pegler, promotes store identity. A store whose appearance communicates quality attracts customers interested in quality; a bargain basement atmosphere encourages expectations for lower prices.

- Customer Service

For small stores forced to minimize their staffing level, visual merchandising enables customers to see and feel items without asking for help. Displays showcase product features to educate customers and answer their questions. Well-placed signs and the arrangement of stock in a logical sequence -- bed pillow next to sheets, for example -- help shoppers find what they need. Visual product placement also gives customers ideas on how to use a product in a new way or how to coordinate an item with others, as well as introduce a new look, trend or product. Keeping shoppers well informed quietly enhances customer service while stimulating sales.

- Sales

At the heart of visual merchandising lies its ability to trigger an emotional reaction that leads a customer to buy. Strategically located floor displays guide shoppers through departments, while eye-catching fixture set-ups entice them to stop along the way. Lighting, color and props can attract browsers and turn them into buyers. Displays that use a theme, or visual story, to present product assortments encourage both add-on and multiple sales. For example, presenting beach towels, swimsuits, cover-ups, sunglasses and flip-flops together in a "swim shop" persuades someone preparing for a cruise to purchase a coordinated look. 
- Shopping Experience

Visual merchandising inspires shoppers so they leave the store happy. It adds an entertainment factor to shopping. Returning customers soon tire of seeing the same merchandise displayed the same way. By frequently moving things around and introducing new props and signage, a retailer can give his store a newness and freshness that lends an air of excitement. A regularly changed visual merchandising plan simultaneously invites shoppers to enjoy their shopping experience and reinforces a store's success in their eyes.

- Purpose of Visual Merchandising

Retail professionals display to make the shopping experience more comfortable, convenient and customer friendly by:

$\S$ Making it easier for the shopper to locate the desired category and merchandise.

$\S$ Making it easier for the shopper to self-select.

$\S$ Making it possible for the shopper to co-ordinate \& accessorize.

$\S$ Informing about the latest fashion trends by highlighting them at strategic locations.

Merchandise presentation refers to most basic ways of presenting merchandise in an orderly, understandable, 'easy to shop' and 'find the product' format. This easier format is especially implemented in fast fashion retailers.

\section{VM helps in:}

$\S$ Educating the customers about the product/service in an effective and creative way.

$\S$ Establishing a creative medium to present merchandise in $3 \mathrm{D}$ environment, thereby enabling long lasting impact and recall value.

$\S$ Setting the company apart in an exclusive position.

$\S$ Establishing linkage between fashion, product design and marketing by keeping the product in prime focus.

$\S$ Combining the creative, technical and operational aspects of a product and the business.

$\S$ Drawing the attention of the customer to enable him to take purchase decision within shortest possible time.

II VI CONSUMER BEHAVIOR: Consumer "An Individual who buys goods and services for his or his own use, for the use of households, as a gift for a friend. In each of these contexts the products are bought for final use by individuals, who are referred as end users or ultimate consumers. Consumer Behavior Defined as " the behavior that consumers display in searching for, purchasing, using, evaluating and disposing of the products and services that they expect will satisfy their needs.

\section{Consumer Behavior in a world Economic Instability.}

We need to address the recession and the widespread economic downturn in consumer confidence that was at least, in part initially caused by a dramatic drop in both home prices and sale of homes. This was followed by striking decline in stock prices and therefore the value of stocks which in turn was followed by equally striking massive job lay-offs and cut-backs. This meant that many investors found that a significant portion of their financial holdings set aside for retirement, home purchases, children education and so on, were disappearing in front of their own eyes as banks were failing. All the negative occurrences happened in a relative short period of time creating enormous downturn in the Indian Economy which has resulted in a significant negative impact on consumers with respect to wide range of purchasing all over the world. The entire situation has occurred only because of the emotional purchasing behavior exhibited by the consumers, attracted by the different promotional strategies designed and operated by the Business Organizations.

\section{Emotional Purchase}

Emotional Motives imply the selection of goals according to personal or subjective criteria ( eg., Pride, Fear, Affection or Status ). A recent study found that emotions arising from buying or not buying, when facing an unintended purchase, impact the impression of Advertising Viewed Subsequently.

People who gave in when tempted, and made an unintended purchase preferred subsequent happiness appeals while those who refrained from buying preferred Pride Appeals.

Impulse purchasing is formally defined as a purchase i.e., 1) Unplanned, 2) The result of the exposure to a stimuli 3) Decided on the spot.

\section{Unplanned Purchase}

A Buying Action undertaken without a problem having been previously recognized or a buying intention formed prior to entering into the store. 


\section{Exposure to Stimuli}

A review of consumer research literature indicates that the stimuli associated to impulse purchasing can be categorized along four broad dimensions :

a) In response to marketers suggestions

b) As a result of Marketers Environmental Manipulation

c) Non-Satisfactory or Unavailable Planned Purchases

d) Artistic Stimulation as a potential origin of Impulse purchase.

\section{On-The-Spot}

Defined as the Immediate Time and place where the purchase decision is processed and made.
a) On the Spur of the Moment
b) Spontaneously
c) Suddenly

\section{Data Collection And Findings}

In response to know the impact of visual merchandising on Middle Class families of Hyderabad City, survey was conducted with a sample questionnaire. As a matter of fact the study is almost an empirical one, so as far as possible attempt was made to gather Primary Data, meanwhile personal interviews and observations were also made to know the opinion of Family Heads in the Population.

The Primary Research was carried out in Five Super Markets located in the Hyderabad City and the information was collected from customers who are the Decision Makers in the Family. The following's are the psychological, behavioral aspects which are affected by the extent of Visual Merchandising on Shopping Experience. In case, purchases were made family members are happy whereas the Head of the Family, the Income generator who is effected by the excess expenditure causing Budget Constraint by the Impulse Purchasing Decisions made by the member. If the sales have not happened which might lead to some disturbances as follows?

\section{Consequences occurred}

(a) Egoism :- Whenever they are unable to get or satisfy their needs \& wants in the retail outlet They starts developing or thinking our self and considering our self better and more important than other people which is a bad sign

(b) Misunderstanding: - Both the parties are not clear in identifying the Needs \& Wants of the others. Therefore people start differentiating others which leads to social disturbances in the family.

(c) Miscommunication: - Whenever people misunderstand themselves immediately miscommunication is happened. So, there is a gap between family members in sharing of values, norms and ideas which is pathetic in nature.

(d) Productivity: - Most of the respondents said that when they carry the same emotions to their work places there will be the sudden fall of rate, at which they can perform their duties \& responsibilities.

(e) Frustration: - At the time of observation it is very clear that some respondents feel annoyed on less confident because they cannot achieve what they want in the retail outlet.

(f) Sustainability: - Because of the excess budget there is a fear of sustainability. Sometimes it is not easy to continue the minimum requirements of the family which leads to even debts also.

(g) Autonomy: - This is mostly effected area in children's behavior if they can't get what they need. They starts organize their own activities and maintain individuality which leads to uncontrolled over activities.

\section{DEDMOGRAPHIC PROFILE OF RESPONDENTS}

$\begin{array}{llllll}\begin{array}{l}\text { age group } \\ \text { frequency }\end{array} & 20-30 & 31-40 & 41-50 & 51-60 & 60 \text { above } \\ & 6 & 33 & 46 & 24 & 11 \\ \text { income } & <10000 & 10000-20000 & 20000-30000 & 30000-40000 & \text { above } 40000 \\ \text { frequency } & 12 & 68 & 15 & 8 & 17 \\ \text { education } & \text { ssc } & \text { inter } & \text { graduation } & \text { post graduations } & \text { doctorate } \\ \text { frequency } & 8 & 22 & 55 & 31 & 4 \\ & & & & & \\ \text { family status } & \text { low } & \text { middle } & \text { middle upper } & \text { upper } & \text { other } \\ \text { frequency } & 10 & 45 & 35 & 22 & 8\end{array}$




\begin{tabular}{|c|c|c|c|c|c|}
\hline $\begin{array}{l}\text { shopping } \\
\text { with family } \\
\text { in a month }\end{array}$ & never & 1--2 times & 3--4 times & 5--6 times & above 6 times \\
\hline frequency & 4 & 68 & 43 & 7 & 3 \\
\hline $\begin{array}{l}\text { criteria for } \\
\text { selection of } \\
\text { store }\end{array}$ & $\begin{array}{l}\text { brand } \\
\text { image }\end{array}$ & $\begin{array}{l}\text { size of } \\
\text { store }\end{array}$ & nearness & assortment & other factors \\
\hline frequency & 25 & 88 & 14 & 75 & 12 \\
\hline $\begin{array}{l}\text { In store } \\
\text { factors of } \\
\text { purchases }\end{array}$ & price & $\begin{array}{l}\text { sales } \\
\text { personnel }\end{array}$ & $\begin{array}{l}\text { visual } \\
\text { merchandising }\end{array}$ & offers & others \\
\hline frequency & 18 & 5 & 101 & 34 & 8 \\
\hline $\begin{array}{l}\text { elements in } \\
\text { visual } \\
\text { merchandise }\end{array}$ & lighting & displays & mannequins & $\begin{array}{l}\text { fixtures and } \\
\text { textures }\end{array}$ & $\begin{array}{l}\text { props and } \\
\text { others }\end{array}$ \\
\hline frequency & 13 & 46 & 27 & 9 & 6 \\
\hline
\end{tabular}

IV. Tables And Figures

Table : (1) Type of purchasing behavior exhibited by family members.

\begin{tabular}{|l|l|l|}
\hline Type of behavior & No: respondents & \% of respondents \\
\hline Rational & 18 & 15.51 \\
\hline Impulsive & 98 & 84.48 \\
\hline & Total 116 & Total 100 \\
\hline
\end{tabular}

\section{TYPE OF BEHAVIOR}

TABLE : (2) does impulse purchase has impact on budget

\begin{tabular}{|l|l|l|}
\hline opinion & No: of respondents & \% of respondents \\
\hline yes & $\mathbf{9 5}$ & 79.16 \\
\hline no & $\mathbf{2 5}$ & 20.83 \\
\hline & Total 120 & Total 100 \\
\hline
\end{tabular}




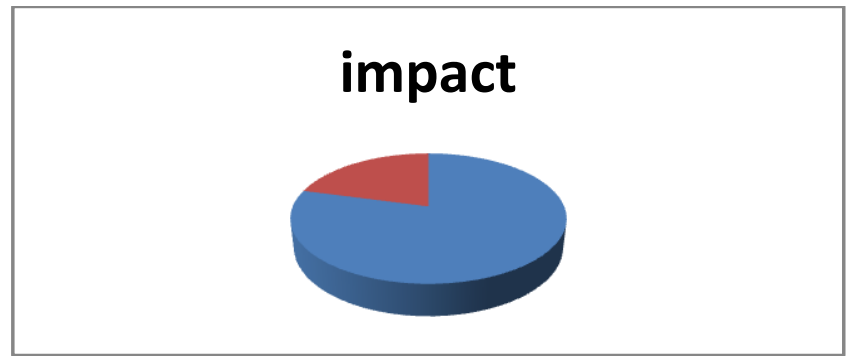

Table : 3 is excess budget leading to social disturbance?

\begin{tabular}{|c|c|c|}
\hline opinion & No: respondents & \% of respondents \\
\hline Yes & 88 & $\mathbf{9 2 . 6 3}$ \\
\hline no & 07 & $\mathbf{0 7 . 3 6}$ \\
\hline & Total 95 & Total 100 \\
\hline
\end{tabular}

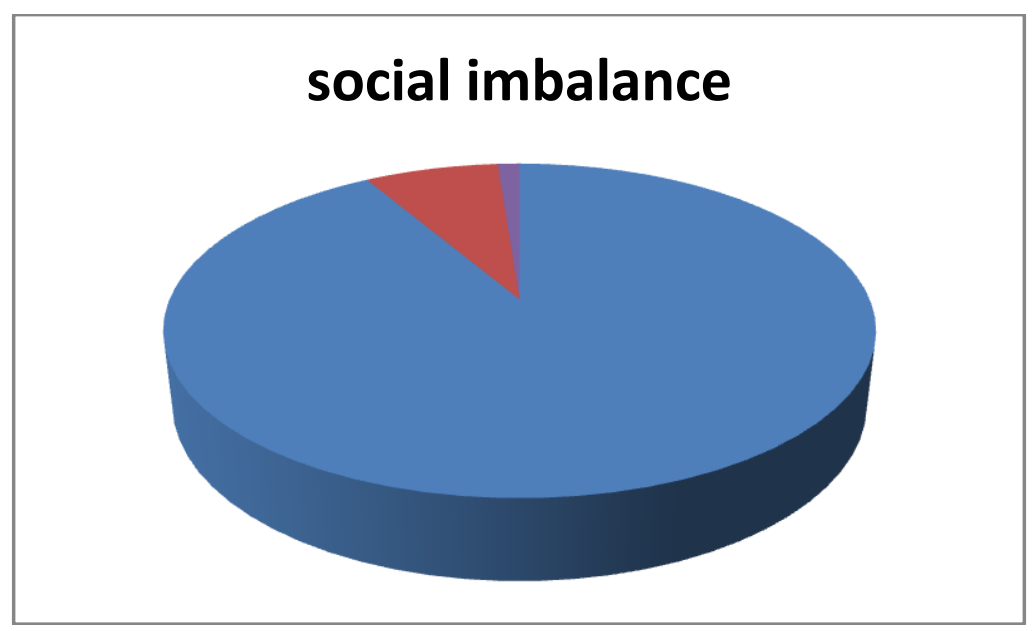

V. Summary

Summary: - Ironically, what is created to satisfy a need. We call want, in the light of customer driven marketing, is becoming motive imperative. Then deviance from Conscience collective has brought societal imbalance because, the very Definition of economy has come to a verge of getting revisited.

An Economic Setting which lays on efficient management and administration of material recourses, gets disturbed by a simple non purchase by a walk-in, because of Inadequate Financial resources.

As we know companies rate their products / services demand potential from a combined patronage of factors, willingness, ability to purchase and desire to purchase of the walk-in.

When the motives of customer are over whelmed only by willing nests and desire to purchase \& not ability to purchase this would lead a disturbance in the consumer profile bringing into fore the frustration, Fragile relationship, Emotional Imbalance, Clash of ego's etc, This affection Balance, Which society strives at.

One little stimulus, a positioning technique can bring a tug between sustainability and individual defiance in his want redressed, causing lack of productivity of groups and then finally effecting the manufacturing of products (or) services merchandising

\section{Figurative Depiction}




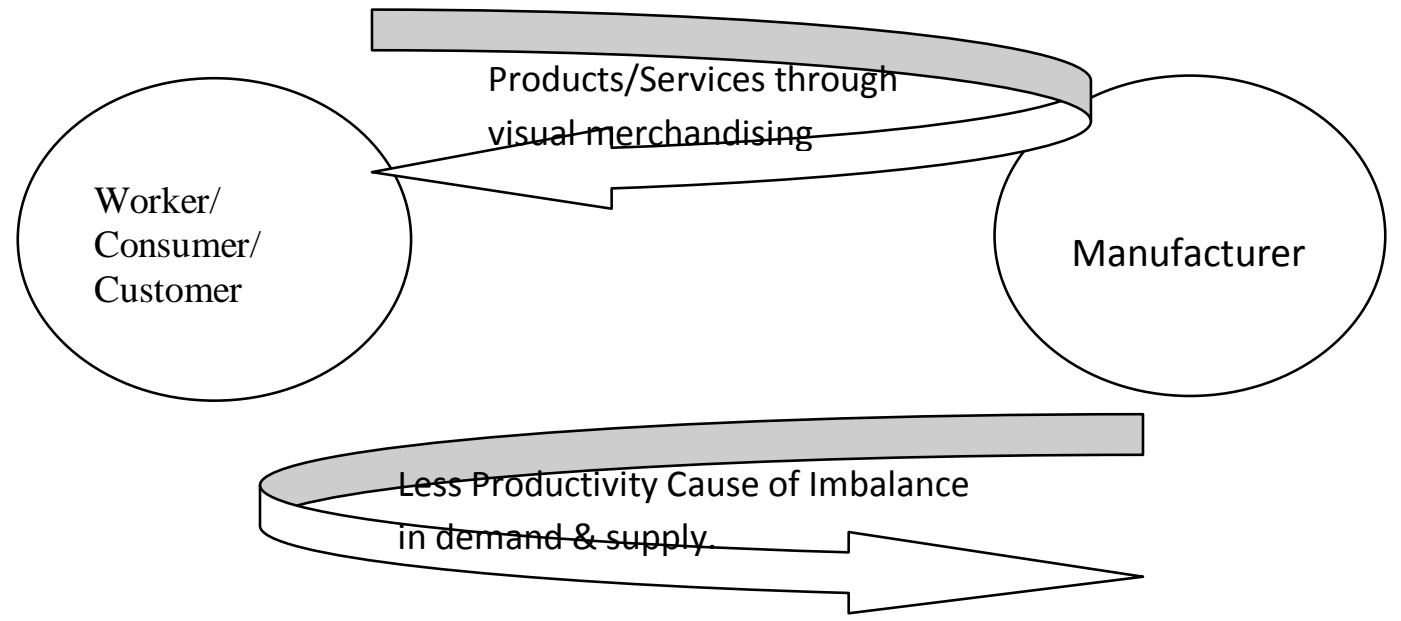

imbalance.

Hence, all Inclusive Consumer Protection legislation would hinder the downside of economic

\section{Conceptualization}

In conceptualizing the study, Researchers have attempted to find out the consequences of impulse purchases made by the consumers or the family members at the retail store because of the visual merchandising in middle class families' in terms of the economic Activity.

Figure: - Conceptual Modeling.

Tools

Consequence

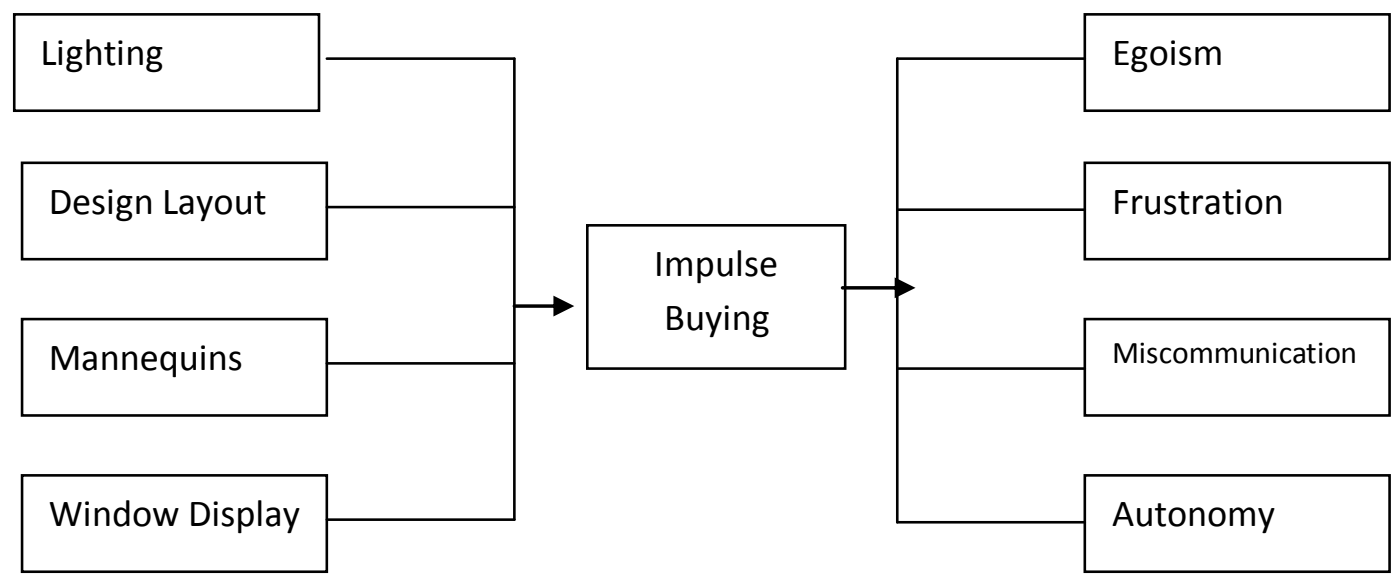

References

[1]. Old pillars of new retailing berry L L, Harvard business review, April 2001, pp 131-137.

[2]. Rocket science retailing is almost here- are you ready, Harvard business review, July-august2000.

[3]. Emerging trends for retailing industry, jagdish $\mathrm{N}$ sheth, journal of retailing, volume59, and fall 1983.

[4]. Retailing; the next ten years, Leonard berry, I h Wilson, journal of retailing, volume53, fall 1977.

[5]. Visual merchandising and display, martin Pegler.

[6]. “Atmospherics as a marketing tool”, kotler, p., journal of retailing, vol. 21, winter 1973-1974.pp.48-64.

[7]. "Impression of retail stores: a content analysis of consumer images:, zimmer,m r . and golden,1 1 ,journal of retailing,vol.64, autumn1988.

[8]. "The influence of store nirioment on quality inferences and store image", baker, j., grewal, d.and parasuraman, a., journal of academy of marketing science,ol. 22, autumn1994.

[9]. The management of retail design: demystifying the activity, Christopher $m$ moore and Malcolm lochhead, $\mathbf{j}$ consumer studies $\&$ home economics, 23,3, September 1998 .

[10]. Michel r. Soloman and elnora w.stuart, mamarketing.real people, real choice, $2^{\text {nd }}$ ed.(upper saddle rier,nj: prentice hall, 2000$): 5-6$.

[11]. Evan Ramstad," walkmans' plan for retailing in the ears of wired youths," wall street journal interactive edition (may 10, 2000).

[12]. Natalie perkins," zeroing in on consumer values," advertising age (march22,

[13]. Areni, C. and Kim, D. (1993). The Influence of Background Music on Shopping Behavior, Classical Versus Top-Forty Music in a Wine Store. Advances in Consumer Research, Vol. 20, 336-340.

[14]. Baker, J., Grewal, D. (1992). An experimental approach to making retail store environmental decisions. Journal of Retailing, Vol. $68,445-60$. 
[15]. Bitner, M.J. (1992). Services capes: the impact of physical surroundings on customers and employees. Journal of Marketing, Vol.56, 57-71.

[16]. Dash, J.F., Schiffman, L.G. and Berenson, C. (1976). Risk and personality- related dimensions of store choice. Journal of Marketing, Vol. 40, 32-9.

[17]. Davis, B. and Ward, P. (2002). Managing Retail Consumption. Wiley, London.

[18]. Hartline,M., Maxham, J., Makee, D.( 2000). Corridors of influence in the dissemination of customer oriented strategy to customer contact service employees. Journal of Marketing, Vol.64, 35-50.

[19]. Kenhove, P., V., Wulf, K. D., and Walter, V. (1999). The impact of task definition on store- attributes saliencies and store choice. Journal of Retailing, Vol. 75 No. 1, 125-37.

[20]. Kerfoot, S.,Davis, B., Ward, p.( 2003). Visual merchandizing and the creation of discernible retail brands. International journal of Retail and Distribution Management, Vol. 31,143-152.

[21]. Kotler, P. (1974). Atmospherics as a marketing tool. Journal of Retailing, Vol.49, 48-64.

[22]. Marsh, H. (1999). Pop Stars of the Retail World. Marketing, January, pp $20-32$.

[23]. Mattson, B.E. (1982). Situational influences on store choice. Journal of Retailing, Vol.58, No. 3, 46-58.

[24]. McGoldrick, P. (1990). Retail Marketing, Maidenhead.: McGraw-Hill,

[25]. McGoldrick, P. (2002). Retail Marketing ( $2^{\text {nd }}$ Edition), Maidenhead: McGraw-Hill.

[26]. Milliman, R. (1982). Using Background Music to Affect the Behavior of Supermarket Shoppers. Journal of Marketing, Vol. 46, 8691.

[27]. Omar, O. Retail Marketing, Pitman Publishing, London, 1999.

[28]. Schiffmen, L.G., Kanuk, L.K. (2000). Consumer Behaviour. India: Pearson Education Inc.

[29]. Singa, P.K. Banergy A. (2004). Store choice behaviour in an evolving market, International Journal of Retail and Distribution Management, Vol. 32, 2004, 482-494.

[30]. Treblanche, N. S. (1999). The perceived benefit derived from visits to a super regional shopping centre. South African Journal of business, Vol. 30 No. 4, 41-6.

[31]. Walters, D and White, D.( 1987.). Retail Marketing Management, Basingstock: Macmillan Press, ,

[32]. Woodside, A.G., Trappery, R.J. and Randolph, J. (1992). Finding out why customers shop your store and buy your brand: automatic cognitive processing models of primary choice. Journal of Advertising Research, 59-78.

[33]. Yavas. U. (2001). "Patronage motives and product purchase patterns: a correspondence analysis" February 19. http://www.emeraldlibrary.com/ft

[34]. Zeithaml, V. (1988). Consumer perception of price, quality and value: a means-end model and synthesis of evidence, Journal of Marketing, Vol.52, 2-22

[35]. Areni, C. and Kim, D. (1993). The Influence of Background Music on Shopping Behavior, Classical Versus Top-Forty Music in a Wine Store. Advances in Consumer Research, Vol. 20, 336-340.

[36]. Baker, J., Grewal, D. (1992). An experimental approach to making retail store environmental decisions. Journal of Retailing, Vol. 68, 445-60.

[37]. Baker, J., Grewal, D. and Parasuraman, A. (1994). The Effect of Store Atmosphere on Consumer Quality Perceptions and Store Image. Journal of the Academy of Marketing Science, 23-34.

[38]. Baker, J., Grewal, D., Levy, Parasuraman, A. and Glenn, B. (2002). The influence of multi-store environmental clues on perceived merchandise valve and patronage intentions. Journal of Marketing, Vol. 66,120-41.

[39]. Bitner, M.J. (1992). Services capes: the impact of physical surroundings on customers and employees. Journal of Marketing, Vol.56, 57-71.

[40]. Dash, J.F., Schiffman, L.G. and Berenson, C. (1976). Risk and personality- related dimensions of store choice. Journal of Marketing, Vol. 40, 32-9

[41]. Davis, B. and Ward, P. (2002). Managing Retail Consumption. Wiley, London.

[42]. Hartline,M., Maxham, J., Makee, D.( 2000). Corridors of influence in the dissemination of customer oriented strategy to custo mer contact service employees. Journal of Marketing, Vol.64, 35-50.

[43]. Kenhove, P., V., Wulf, K. D., and Walter, V. (1999). The impact of task definition on store- attributes saliencies and store choice. Journal of Retailing, Vol. 75 No. 1, 125-37.

[44]. Kerfoot, S.,Davis, B., Ward, p.( 2003). Visual merchandizing and the creation of discernible retail brands. International journal of Retail and Distribution Management, Vol. 31,143-152.

[45]. Kotler, P. (1974). Atmospherics as a marketing tool. Journal of Retailing, Vol.49, 48-64

[46]. Marsh, H. (1999). Pop Stars of the Retail World. Marketing, January, pp $20-32$.

[47]. Mattson, B.E. (1982). Situational influences on store choice. Journal of Retailing, Vol.58, No. 3, 46-58.

[48]. McGoldrick, P. (1990). Retail Marketing, Maidenhead.: McGraw-Hill,

[49]. McGoldrick, P. (2002). Retail Marketing ( $2^{\text {nd }}$ Edition), Maidenhead: McGraw-Hill.

[50]. Milliman, R. (1982). Using Background Music to Affect the Behavior of Supermarket Shoppers. Journal of Marketing, Vol. 46, 8691.

[51]. Omar, O. Retail Marketing, Pitman Publishing, London, 1999.

[52]. Schiffmen, L.G., Kanuk, L.K. (2000). Consumer Behaviour. India: Pearson Education Inc.

[53]. Singa, P.K. Banergy A. (2004). Store choice behaviour in an evolving market, International Journal of Retail and Distribution Management, Vol. 32, 2004, 482-494.

[54]. Treblanche, N. S. (1999). The perceived benefit derived from visits to a super regional shopping centre. South African Journal of business, Vol. 30 No. 4, 41-6.

[55]. Walters, D and White, D.( 1987.). Retail Marketing Management, Basingstock: Macmillan Press, ,

[56]. Woodside, A.G., Trappery, R.J. and Randolph, J. (1992). Finding out why customers shop your store and buy your brand: automatic cognitive processing models of primary choice. Journal of Advertising Research, 59-78.

[57]. Yavas. U. (2001). "Patronage motives and product purchase patterns: a correspondence analysis" February 19. http://www.emeraldlibrary.com/ft

[58]. Zeithaml, V. (1988). Consumer perception of price, quality and value: a means-end model and synthesis of evidence, Journal of Marketing, Vol.52, 2-22. 